\title{
Gas geochemistry for the Los Azufres (Michoacán) geothermal reservoir, México
}

\author{
Rosa María Barragán ( $\left.{ }^{1}\right)$, Victor M. Arellano Gómez $\left({ }^{1}\right)$, Enrique Portugal ( $\left.{ }^{1}\right)$, \\ Fernando Sandoval $\left({ }^{2}\right)$ and Nuria Segovia $\left({ }^{3}\right)$ \\ (') Instituto de Investigaciones Eléctricas, Gerencia de Geotermia, Cuernavaca, Morelos., México \\ (') Comisión Federal de Electricidad, Residencia Los Azufres, \\ Campamento Aguafría, Los Azufres, Michoacán, México \\ $\left(^{3}\right)$ Instituto de Geofisica, Universidad Nacional Autónoma de Mexico (UNAM), México D.F., México
}

\begin{abstract}
Gas data of the Los Azufres geothermal field were analyzed using a method based on equilibrium of the Fischer-Tropsch (FT) reaction: $\mathrm{CH}_{4}+2 \mathrm{H}_{2} \mathrm{O}=4 \mathrm{H}_{2}+\mathrm{CO}_{2}$ and on the combined pyrite-hematite-magnetite (HSH2) reactions: $5 / 4 \mathrm{H}_{2}+3 / 2 \mathrm{FeS}_{2}+3 / 4 \mathrm{Fe}_{2} \mathrm{O}_{3}+7 / 4 \mathrm{H}_{2} \mathrm{O}=3 \mathrm{H}_{2} \mathrm{~S}+\mathrm{Fe}_{3} \mathrm{O}_{4}$ in order to estimate reservoir temperature and excess steam. The solution of equilibrium equations produces a grid (FT-HSH2). This method is suitable for reservoirs with relatively high $\mathrm{H}_{2} \mathrm{~S}$ but low $\mathrm{H}_{2}$ and $\mathrm{NH}_{3}$ concentrations in the fluid as is the case of the Los Azufres well discharges. Reservoir temperature and reservoir excess steam values were estimated for initial and present conditions in representative wells of the field to study the evolution of fluids, because of exploitation and waste fluids reinjection. This method was very useful in estimating reservoir temperatures in vapor wells, while in two-phase wells it was found that as the well produces a smaller fraction of water, the reservoir temperature estimation agrees qualitatively with results from cationic or silica geothermometers. For liquid-dominated wells the reservoir temperature estimations agree with temperatures obtained from the well simulator wELFLO. This indicates that FT-HSH2 results provide the temperature of the fluid entering the well where the last equilibrium occurs. Results show a decrease in reservoir temperatures in the southern zone of the field where intensive reinjection takes place. With exploitation, it was also noted that the deep liquid phase in the reservoir is changing to two-phase increasing the reservoir steam fraction and the non-condensable gases in well discharges.
\end{abstract}

Key words Los Azufres geothermal field - gas geochemistry - geothermal gas equilibria - reservoir exploitation

\section{Introduction}

Gas geochemistry is useful in geothermal exploration and exploitation, especially in vapordominated fields where very little is known about the deep reservoir liquid. Several gas geother-

Mailing address: Dr. Rosa María Barragán Reyes, Instituto de Investigaciones Eléctricas, Gerencia de Geotermia, Reforma St. 113, Col. Palmira, 62490 Cuernavaca, Morelos, México; e-mail: rmb@iie.org.mx mometers have been proposed (D'Amore and Panichi, 1980; Arnórsson and Gunnlaugsson, 1985), based on the variation of gas ratios with temperature in producing aquifers. Also methods to estimate the reservoir excess steam have been proposed (Giggenbach, 1980; D'Amore and Celati, 1983), which are useful when the reservoir temperature is available. The reservoir excess steam is very important in the assessment of vapor-dominated geothermal fields to calculate the in situ liquid saturation. Methods to estimate both the reservoir temperature and the reservoir excess steam were developed by considering gas equilibria and mineral buffers in the reservoir (D'Amore and Truesdell, 1985, 1995; D'Amore, 1998). D'Amore (1998) developed a method based on equilibria for the Fischer-Tropsch reac- 
tion and the combined expressions for pyritemagnetite and pyrite-hematite mineral buffers. In this method more local oxidant conditions are assumed, implying the occurrence of high concentrations of $\mathrm{H}_{2} \mathrm{~S}$ and relatively low concentrations of both $\mathrm{H}_{2}$ and $\mathrm{NH}_{3}$ in the fluid. The method was suitable for gas data from the Los Humeros geothermal system in order to understand the dynamics of the reservoir at initial and present conditions (Arellano et al., 1998; Barragán et al., 1999, 2000a,b). Siega et al. (1999) described this method and an additional method based on the pyrite-pyrrhotite reaction. They concluded that the method based on FT-HSH2 equilibria best fits mature and magmatic systems data. The ob- jective of this work is to investigate the effects of exploitation in Los Azufres reservoir with time through the changes in both the reservoir temperature and the excess reservoir steam of wells.

\section{The Los Azufres geothermal field}

The Los Azufres geothermal field is an intensely fractured, two-phase, volcanic hydrothermal system located in the northern part of the Mexican Volcanic Axis, in the state of Michoacán at an average elevation of $2800 \mathrm{~m}$ a.s.l. (fig. 1). At present it is the second in the country generating $188 M W_{e}$ (Torres, 2003, pers. comm.). The field

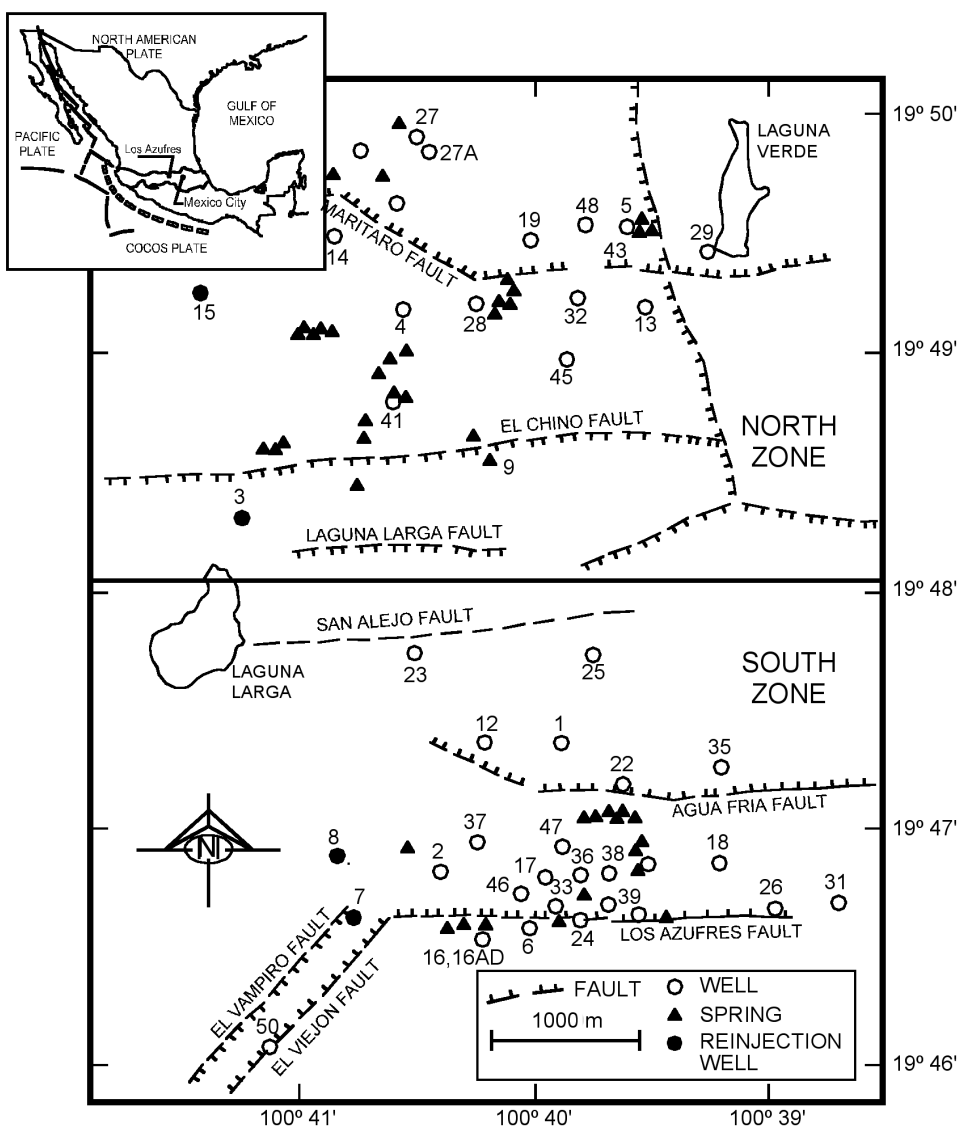

Fig. 1. Location of the Los Azufres geothermal field and wells. AZ-was removed of the name of wells. 
Table I. Average chemical composition of vapor phases of the Los Azufres geothermal wells. $T_{S}$ - separation temperature $\left({ }^{\circ} \mathrm{C}\right) ; y_{\mathrm{SEP}}-$ steam fraction at separation conditions (dimensionless); $\mathrm{Xg}$ - ratio of millimoles of non condensable gas per mol of water vapor and concentration of gas species in \%o molar (dry basis). Average values of FT and HSH2 are also given.

\begin{tabular}{|c|c|c|c|c|c|c|c|c|c|c|c|c|}
\hline Well & Year & $T_{S}$ & $y_{\mathrm{SEP}}$ & $\mathrm{Xg}$ & $\mathrm{CO}_{2}$ & $\mathrm{H}_{2} \mathrm{~S}$ & $\mathrm{H}_{2}$ & $\mathrm{CH}_{4}$ & $\mathrm{~N}_{2}$ & $\mathrm{NH}_{3}$ & FT & HSH2 \\
\hline AZ-5 & 1985 & 180.7 & 0.709 & 13.020 & 978.200 & 14.600 & 3.140 & 0.724 & 2.684 & 0.642 & -15.02 & -5.94 \\
\hline AZ-5 & 1986 & 174.3 & 0.720 & 8.583 & 976.267 & 15.457 & 3.007 & 662 & 2.953 & 1.664 & -15.75 & -6.15 \\
\hline AZ-5 & 1987 & 179.7 & 0.706 & 11.007 & 976.833 & 14.557 & 3.191 & 0.965 & 3.062 & 1.428 & -15.42 & -6.08 \\
\hline AZ-5 & 1998 & 176.1 & 0.850 & 9.898 & 972.915 & 17.625 & 1.560 & 0.542 & 6.662 & 0.700 & -16.27 & -5.38 \\
\hline AZ-5 & 1999 & 178.9 & 0.860 & 15.360 & 972.023 & 16.000 & 2.680 & 0.738 & 7.661 & 0.880 & -14.68 & -5.46 \\
\hline AZ-5 & 2000 & 174.3 & 0.871 & 10.183 & 965.901 & 18.836 & 2.382 & 2.086 & 7.885 & 2.887 & -16.04 & -5.49 \\
\hline AZ-5 & 2001 & 175.0 & 0.892 & 13.916 & 902.032 & 12.813 & 11.298 & 1.246 & 66.408 & 5.987 & -12.55 & -6.58 \\
\hline AZ-6 & 1983 & 192.0 & 1 & 31.700 & 989.000 & 5.900 & 0.900 & 90 & 00 & 0.400 & -14.87 & -5.50 \\
\hline AZ-6 & 1985 & 182.3 & 1 & 35.333 & 982.000 & 6.567 & 1.100 & 0.807 & 6.100 & 3.200 & -14.56 & -5.39 \\
\hline AZ-6 & 1986 & 179.7 & 1 & 34.367 & 979.333 & 6.033 & 1.100 & 0.860 & 8.533 & 3.833 & -14.63 & -5.52 \\
\hline AZ-6 & 1987 & 169.3 & 1 & 31.525 & 979.750 & 6.875 & 1.450 & 943 & 9.550 & 1.200 & -14.34 & -5.57 \\
\hline AZ-6 & 1988 & 170.7 & 0.98 & 42.193 & 978.650 & 5.000 & 1.700 & 0.617 & 13.254 & 0.639 & -13.41 & -5.86 \\
\hline AZ-6 & 1998 & 178.1 & 0.940 & 43.280 & 983.950 & 3.200 & 1.200 & 0.221 & 10.763 & 0.617 & -13.60 & -6.27 \\
\hline AZ-9 & 1984 & 148.0 & 0.456 & 2.100 & 920.100 & 62.300 & 7.412 & 0.385 & 1.083 & 8.685 & -17.22 & -6.24 \\
\hline AZ-9 & 1987 & 182.5 & 0.407 & 2.335 & 944.250 & 42.970 & 3.673 & 0.494 & 6.232 & 2.383 & -18.55 & -6.35 \\
\hline AZ-9 & 1999 & 175.9 & 0.410 & 1.640 & 913.340 & 64.900 & 5.810 & 1.612 & 14.279 & 0.025 & -18.88 & -6.32 \\
\hline AZ-9 & 2000 & 175.3 & 0.424 & 1.350 & 85 & 62 & 600 & 40 & & 14 & & -6.82 \\
\hline AZ-9 & 2001 & 173.5 & 0.467 & 1.565 & 774.574 & 57.755 & 25.747 & 0.536 & 99.396 & 41.744 & -15.74 & -7.22 \\
\hline AZ-13 & 1985 & 172.5 & 0.5785 & 7.630 & 971.600 & 21.000 & 3.748 & 0.560 & 1.781 & 1.311 & -15.89 & -6.12 \\
\hline AZ-13 & 1986 & 172.3 & 0.584 & 5.733 & 961.933 & 27.3 & 5.854 & 0.730 & 44 & 2.150 & -15.71 & -6.23 \\
\hline AZ-13 & 1987 & 171.0 & 0.586 & 7.270 & 967.800 & 20.125 & 6.691 & 0.897 & 2.062 & 2.454 & -15.15 & -6.52 \\
\hline AZ-13 & 1998 & 182.3 & 0.940 & 6.268 & 953.860 & 31.375 & 2.640 & 1.457 & 9.167 & 1.488 & -16.42 & -5.19 \\
\hline AZ-13 & 1999 & 175.8 & 0.945 & 9.080 & 959.440 & 28.500 & 2.470 & 1.289 & 5 . & 2.490 & -15.82 & -4.99 \\
\hline AZ-13 & 2000 & 184.0 & 0.999 & 9.164 & 950.878 & 29.613 & 2.960 & 1.566 & 7.053 & 7.855 & -15.49 & -4.99 \\
\hline AZ-13 & 2001 & 188.5 & 0.992 & 9.969 & 894.289 & 29.350 & 9.487 & 1.546 & 58.146 & 6.661 & & -5.58 \\
\hline AZ-17 & 1984 & 174.0 & 1 & 17.850 & 987.500 & 6.450 & 2.450 & 0.195 & 1.400 & 1.600 & -13.73 & -6.37 \\
\hline AZ-17 & 1985 & 159.0 & 1 & 33.675 & 980.000 & 9.175 & 2.275 & 0.363 & 5.625 & 2.200 & -13.03 & -5.39 \\
\hline AZ-17 & 1986 & 200.0 & 1 & 15.967 & 975.667 & 11.300 & 1.967 & 0.303 & 5.500 & 5.200 & -14.50 & -5.60 \\
\hline AZ-17 & 1987 & 185.8 & 1 & 15.900 & 973.500 & 12.875 & 3.400 & 0.290 & 7.625 & 1.725 & -13.54 & -5.73 \\
\hline AZ-17 & 1988 & 169.0 & 1 & 12.367 & 968.333 & 13.500 & 4.033 & 0.473 & & 1.433 & -13.90 & -5.95 \\
\hline AZ-17 & 1998 & 173.5 & 1 & 9.700 & 883.860 & 12.500 & 7.030 & 0.197 & 96.323 & 0.124 & -13.01 & -6.54 \\
\hline AZ-17 & 2000 & 173.5 & 1 & 12.550 & 875.190 & 12.800 & 7.130 & 0.309 & 104.177 & 0.444 & -12.74 & -6.32 \\
\hline AZ-17 & 2001 & 179.0 & 0.999 & 13.552 & 859.988 & 12.440 & 10.515 & 0.540 & 109.734 & 6.283 & -12.18 & -6.51 \\
\hline AZ-33 & 1984 & 206.0 & 0.842 & 27.570 & 986.600 & 7.640 & 1.956 & 0.610 & 2.424 & 0.815 & -14.16 & -5.82 \\
\hline AZ-33 & 1998 & 180.3 & 0.560 & 13.560 & 961.030 & 8.900 & 2.080 & 0.629 & 25.384 & 1.989 & -16.02 & -6.51 \\
\hline AZ-33 & 1999 & 177.6 & 1 & 9.010 & 942.830 & 19.500 & 6.820 & 0.062 & 30.193 & 0.633 & -12.66 & -6.00 \\
\hline AZ-33 & 2000 & 181.7 & 0.530 & 16.430 & 934.820 & 9.000 & 3.540 & 0.435 & 52.008 & 0.227 & -14.71 & -6.68 \\
\hline AZ-33 & 2001 & 178.4 & 0.608 & 16.519 & 937.275 & 10.240 & 6.210 & 0.964 & 39.919 & 5.290 & -13.83 & -6.71 \\
\hline
\end{tabular}


is divided into two zones: Maritaro a liquid-dominated zone in the north and Tejamaniles a steamdominated zone in the south.

Iglesias et al. (1985) found that in its natural state the Los Azufres geothermal field consists of a deep aquifer where the ascending fluid starts boiling at about $1200 \mathrm{~m}$ a.s.l. The twophase liquid dominant region extends upwards from $1200 \mathrm{~m}$ a.s.l. to about $1700 \mathrm{~m}$ a.s.l. where steam becomes the dominant phase. The twophase steam dominated region extends up to about $2400 \mathrm{~m}$ a.s.l. where a region of dry or superheated steam is located.

According to Cathelineau et al. (1985), the most important hydrothermal minerals occurring at the Los Azufres geothermal system are: chlorite, pyrite, hematite, epidote, calcite, albite, adularia, zeolite and quartz which were formed by alteration of primary minerals: olivine, pyroxene/ amphiboles, biotite, feldspar and rock-matrix.

The Los Azufres reservoir geochemical model was proposed by Nieva et al. (1987). This model was based on the spatial distribution of chemical and isotopic species at reservoir conditions. The reservoir excess steam $y$ was estimated for the wells by a method based on equilibrium of the Fischer-Tropsch reaction (Giggenbach, 1980; Nieva et al., 1987). The $y$ values were obtained at the reservoir temperature estimated by the cationic (CCG; Nieva and Nieva, 1987) and silica (Fournier and Potter II, 1982) geothermometers in two-phase wells, whereas measured temperatures were taken in vapor wells. The $y$ values were used to correct the chemical and isotopic composition of the total discharge to obtain the reservoir «reference» values. As the concentration of volatile species $\left(\mathrm{CO}_{2}\right)$ was larger in shallower strata and concentrations of non-volatile species (chlorides and oxygen-18 in the fluid) increased with depth, the model establishes the occurrence of a reservoir steam up-flow with partial condensation process, to explain the distributions of species as observed. According to the geochemical model, this behavior seems to be dominant in the southern zone while for the north, the presence of two different liquid phases (with slightly different isotopic composition) was proposed.

The separated water in the Los Azufres twophase wells is of sodium-chloride type with neutral $p H$ at separating conditions. The deep reservoir fluid contains up to $1600 \mathrm{ppm}$ of chloride and the molar fraction of $\mathrm{CO}_{2}$ has been calculated between 0.3 to 8.3 (Nieva et al., 1987). The $p H$ of fluids at the reservoir is neutral with values between 5.5 and 7.4 (Barragán et al., 1988). The CCG geothermometer (Nieva and Nieva, 1987) provided reservoir temperatures of more than $300^{\circ} \mathrm{C}$ for the north zone, whereas slightly lower values between 270 and $290^{\circ} \mathrm{C}$ were estimated for the south.

The well discharges in the Los Azufres geothermal field contain a relatively high amount of non-condensable gases compared to other fields (table I), i.e. the vapor well AZ-6 contains more than $40 \%$ molar of non condensable gas in steam, though liquid dominated wells such as AZ-4 contain only about $2 \%$. Typically, the main constituent in dry gas is $\mathrm{CO}_{2}$ (average $94 \mathrm{vol} \%$ ), then $\mathrm{H}_{2} \mathrm{~S}$ (average 2.5 vol\%) while $\mathrm{H}_{2}, \mathrm{CH}_{4}, \mathrm{~N}_{2}$ and $\mathrm{NH}_{3}$ concentrations are minor (average $3.5 \mathrm{vol} \%$ all of them). In wells affected by reinjection, $\mathrm{N}_{2}$ concentration has increased since a mixture of water/air is injected into the reservoir.

\section{Gas equilibria}

The chemical composition of geothermal gases depends mainly on temperature, pressure, vapor/liquid gas distribution processes and those secondary processes caused by different kinetic responses to changes in temperature and redox potential during the rise of the fluid to the surface (Giggenbach, 1980). Thus, large variations in gas compositions occur in different geothermal fields, but also in the same field among different wells. Giggenbach (1980); D'Amore and Truesdell $(1985,1995)$ and D'Amore (1998) developed methods based on gas equilibria considering mineral buffers in order to estimate physical characteristics of reservoirs. The mineral buffers controlling the hydrogen-hydrogen sulfide geothermal reaction at temperatures above $300^{\circ} \mathrm{C}$ were pyrite, pyrrhotite and magnetite while for temperatures around $240^{\circ} \mathrm{C}$ iron-aluminium-silicate minerals replace magnetite. Calcite and anhydrite can also be used as buffers for geothermal gases since they are commonly found in geothermal systems, but anhy- 
drite is likely to reveal more oxidizing conditions occurring at the periphery of geothermal systems (Giggenbach, 1980). However the fluid-mineral reactions may be different for different geothermal reservoirs depending not only on temperature but also on the rock type (D'Amore and Truesdell, 1985).

Giggenbach (1987) and Taran et al. (2002) suggest evaluating the ratio of fugacities $R_{H}=$ $=\log \left(f_{\mathrm{H}_{2}} / f_{\mathrm{H}_{2} \mathrm{O}}\right)$, of $\mathrm{H}_{2}$ and $\mathrm{H}_{2} \mathrm{O}$ in order to investigate predominating redox conditions within the reservoir. For most hydrothermal fluids the redox state is controlled by $\mathrm{FeO}-$ $\mathrm{FeO}_{1.5}$ and hematite-fayalite-quartz assemblages, $R_{H}$ values are temperature independent at -2.8 . For vapor dominated geothermal systems values of $R_{H}$ close to -2.8 are found. Values above -2.8 are considered to be typical of reducing conditions and are found in high-temperature (about $800^{\circ} \mathrm{C}$ ) volcanic gases (Taran et al., 2002) whereas values below -2.8 are considered oxidizing conditions and are characteristic of geothermal systems. Figure 2 (modified from Giggenbach, 1987 and Taran et al., 2002) shows total discharge $R_{H}$ values

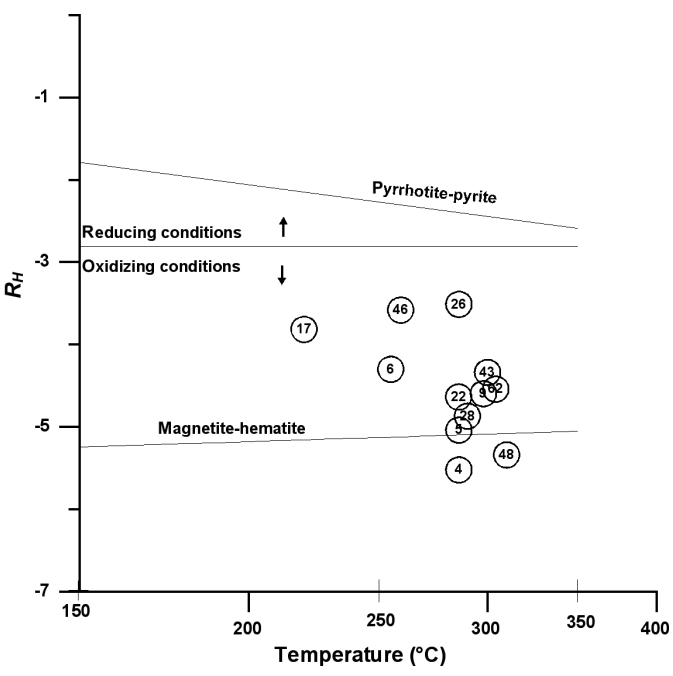

Fig. 2. $R_{H}$ values for total discharge fluids of Los Azufres wells. for some Los Azufres wells versus the reservoir temperature. As expected, the $R_{H}$ values indicate oxidizing conditions at reservoir $\left(R_{H}\right.$ values less than -2.8) for all the wells.

D'Amore (1998) developed a method using the Fischer-Tropsch and another reaction for the $\mathrm{H}_{2} \mathrm{~S}-\mathrm{H}_{2}$ couple which was obtained from the combined pyrite-hematite, pyritemagnetite equilibrium named $\mathrm{HSH} 2$. This method was fully described by D'Amore (1998), Siega et al. (1999), Barragán et al. (1999, 2000a, 2001). It is based on reactions (3.1) and (3.2)

$$
\begin{aligned}
& \text { (FT) } \mathrm{CH}_{4}+2 \mathrm{H}_{2} \mathrm{O}=4 \mathrm{H}_{2}+\mathrm{CO}_{2} \\
& (\mathrm{HSH} 2) \quad 5 / 4 \mathrm{H}_{2}+3 / 2 \mathrm{FeS}_{2}+3 / 4 \mathrm{Fe}_{2} \mathrm{O}_{3}+ \\
& +7 / 4 \mathrm{H}_{2} \mathrm{O}=3 \mathrm{H}_{2} \mathrm{~S}+\mathrm{Fe}_{3} \mathrm{O}_{4} .
\end{aligned}
$$

The thermodynamic equilibrium constant $K$ for each reaction is given in eqs. (3.3) and (3.4), in terms of the partial pressures

$$
\begin{aligned}
& \log K_{\mathrm{FT}}=4 \log P_{\mathrm{H}_{2}}+\log P_{\mathrm{CO}_{2}}+ \\
& -\log P_{\mathrm{CH}_{4}}-2 \log \mathrm{P}_{\mathrm{H}_{2} \mathrm{O}} \\
& \log K_{\mathrm{HSH} 2}=3 \log P_{\mathrm{H}_{2} \mathrm{~S}}+ \\
& -5 / 4 \log P_{\mathrm{H}_{2}}-7 / 4 \log P_{\mathrm{H}_{2} \mathrm{O}}
\end{aligned}
$$

and writing the constants in terms of the water partial pressure, according to (D'Amore, 1992)

$$
\log P_{i}=\log \left(n_{i} / n_{\mathrm{H}_{2} \mathrm{O}}\right)-\log A_{i}+\log P_{\mathrm{H}_{2} \mathrm{O}}
$$

where $\left(n_{i} / n_{\mathrm{H}_{2} \mathrm{O}}\right)$ is the molar ratio of $i$ component regarding the total water. The coefficient $A$ for every species $i$ is defined as a function of temperature and the steam fraction $y$

$$
\begin{aligned}
& A_{i}=y+(1-y) / B_{i} \quad \text { if } y \geq 0 \\
& A_{i}=1 /\left(B_{i}\left(1+y-y B_{i}\right)\right) \quad \text { if } y<0
\end{aligned}
$$

$B_{i}$ is the distribution coefficient for every gas and it is a function of temperature (Giggenbach, 1980; D'Amore, 1992). For temperatures between 100 and $340^{\circ} \mathrm{C}\left(t\right.$ in $\left.{ }^{\circ} \mathrm{C}\right)$

$$
\begin{aligned}
& \log B_{\mathrm{CO}_{2}}=4.7593-0.01092 t \\
& \log B_{\mathrm{CH}_{4}}=6.0783-0.01383 t \\
& \log B_{\mathrm{H}_{2} \mathrm{~S}}=4.0547-0.00981 t
\end{aligned}
$$




$$
\log B_{\mathrm{H}_{2}}=6.2283-0.01403 t \text {. }
$$

By substituting in eqs. (3.3) and (3.4) each $P$ expression, as given by eq. (3.5)

$$
\begin{aligned}
& \log K_{\mathrm{FT}_{1}}+4 \log A_{\mathrm{H}_{2}}+\log A_{\mathrm{CO}_{2}}-\log A_{\mathrm{CH}_{4}}+ \\
& -2 \log P_{\mathrm{H}_{2} \mathrm{O}}=4 \log \left(n_{\mathrm{H}_{2}} / n_{\mathrm{H}_{2} \mathrm{O}} \mathrm{O}\right)+ \\
& +\log \left(n_{\mathrm{CO}_{2}} / n_{\mathrm{H}_{2} \mathrm{O}}\right)-\log \left(n_{\mathrm{CH}_{4}} / n_{\mathrm{H}_{2} \mathrm{O}}\right) \\
& \log K_{\mathrm{HSH}_{2}}+3 \log A_{\mathrm{H}_{2} \mathrm{~S}}-5 / 4 \log A_{\mathrm{H}_{2}}= \\
& 3 \log \left(n_{\mathrm{H}_{2} \mathrm{~S}} / n_{\mathrm{H}_{2} \mathrm{O}}\right)-5 / 4 \log \left(n_{\mathrm{H}_{2}} / n_{\mathrm{H}_{2} \mathrm{O}}\right) .
\end{aligned}
$$

The left side of eqs. (3.6) and (3.7) are defined as the FT and $\mathrm{HSH} 2$ parameters

$$
\begin{aligned}
& \mathrm{FT}=\log K_{\mathrm{FT}}+4 \log A_{\mathrm{H}_{2}}+\log A_{\mathrm{CO}_{2}}+ \\
& -\log A_{\mathrm{CH}_{4}}-2 \log P_{\mathrm{H}_{2} \mathrm{O}} \\
& \mathrm{HSH} 2=\log K_{\mathrm{HSH}_{2}}+3 \log A_{\mathrm{H}_{2} \mathrm{~S}}-5 / 4 A_{\mathrm{H}_{2}} .
\end{aligned}
$$

According to D'Amore (1992), the expressions for the equilibrium constants $\left(\log K_{\mathrm{FT}}\right.$ and $\log K_{\mathrm{HSH}}$ ) are given by

$$
\log K_{\mathrm{FT}}=-4.33-(8048 / T)+4.635 \log (T)
$$

$\log K_{\mathrm{HSH} 2}=7.609-(6087 / T)-0.412 \log (T)$

$\log P_{\mathrm{H}_{2} \mathrm{O}}=5.51-(2048 / T)$

where $T$ is given in $K$.

The graphic solution of eqs. (3.8) and (3.9) provides a grid in the coordinates (HSH2, FT). The parameters $\mathrm{FT}$ and $\mathrm{HSH} 2$ are obtained from the gas composition according to eqs. (3.13) and (3.14)

$$
\begin{aligned}
& \mathrm{FT}=4 \log \left(\mathrm{H}_{2} / \mathrm{H}_{2} \mathrm{O}\right)+\log \left(\mathrm{CO}_{2} / \mathrm{H}_{2} \mathrm{O}\right)+ \\
& -\log \left(\mathrm{CO}_{4} / \mathrm{H}_{2} \mathrm{O}\right)
\end{aligned}
$$

$\mathrm{HSH} 2=3 \log \left(\mathrm{H}_{2} \mathrm{~S} / \mathrm{H}_{2} \mathrm{O}\right)-5 / 4 \log \left(\mathrm{H}_{2} / \mathrm{H}_{2} \mathrm{O}\right)$

where concentrations of gas species are taken in the total fluid.

The following trends and interpretations were given by D'Amore and Truesdell (1995):
- Increase $T$, decrease $y$ : contribution of fluid from a hotter and deeper source with high liquid saturation.

- Increase $T$, increase $y$ : apparent increase in $T$ and $y$ due to lateral source of steam, with practically zero liquid saturation and with a strong local accumulation of gas.

- Decrease $T$, decrease $y$ : local source of pure and low temperature water with no gas content as in the case of reinjection fluids or fast meteoric water.

- Decrease $T$, increase $y$ : caused by either recharge from peripheral fluids rich in gas; or sulfides precipitation caused by local over-production with blockage of main fractures.

\section{Results}

\subsection{Tejamaniles steam-dominated south zone}

The southern zone has been intensively exploited since 1984. The wells AZ-6, AZ-17 and AZ-33 were selected as representative. Table II gives the height ( $\mathrm{m}$ a.s.l.) of producing zones of the wells. In fig. 1 the location of wells in the field is given.

Figure 3 shows the FT-HSH2 grid diagram for the steam well AZ-6. In the diagram, the dark mark corresponds to the reference point found by Nieva et al. (1987), calculated through equilibrium of the FT reaction for the measured reservoir temperature. The points represent average values for the indicated years, all data available were included. The figure shows that the grid temperature of about $290^{\circ} \mathrm{C}$ obtained for 1983 probably indicates that of the source of steam, since the reference temperature based on measured reser-

Table II. Height of producing zones of studied wells.

\begin{tabular}{cc}
\hline \hline Well & Elevation (m a.s.l.) \\
\hline AZ-5 & $1740 \pm 330$ \\
AZ-6 & $2015 \pm 100$ \\
AZ-9 & $945 \pm 350$ \\
AZ-13 & $1620 \pm 100$ \\
AZ-17 & $2200 \pm 30$ \\
AZ-33 & $2190 \pm 40$ \\
\hline
\end{tabular}




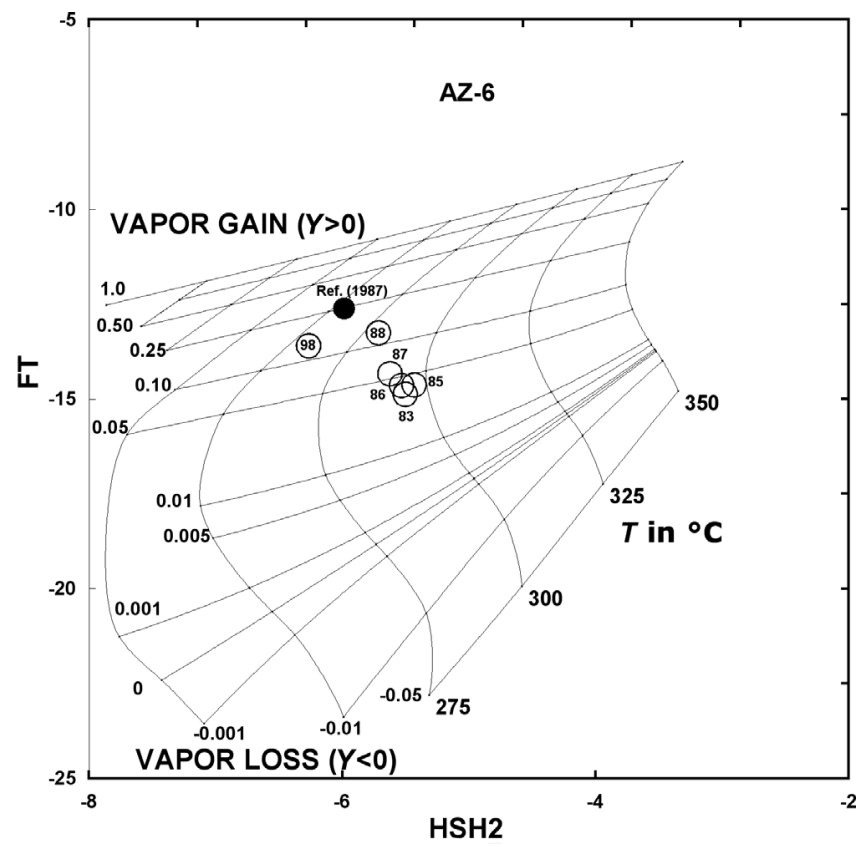

Fig. 3. FT-HSH2 grid diagram for well AZ-6. The dark dot shows the conditions taken as reference before exploitation (Nieva et al., 1987). Circles show the average values for the indicated years. See text for discussion.

voir temperatures is only $260^{\circ} \mathrm{C}$. For the 1983 point, the vapor fraction $(y)$ was very small, about $3 \%$ compared to that obtained for the reference $25 \%$. An overall tendency with 19831998 data shows an important decrease in temperature, of about $30^{\circ} \mathrm{C}$ and an increase in $y$ from 3 to $12 \%$. According to D'Amore and Truesdell (1995), this trend is related to a decrease in the ratio $\mathrm{H}_{2} \mathrm{~S} / \mathrm{H}_{2} \mathrm{O}$ which could be caused either by recharge from peripheral fluids rich in gas or by sulfides precipitation. In well AZ-6 there is evidence of interference of reinjection fluids which are rich in gas. However the increase in $y$ occurred only for the period 1983-1988, since points for 1988-1998 show a constant value of $13 \%$. Thus, for the period of 1988-1998 the drop in temperature was due to exploitation that lowered the reservoir pressure.

Figure 4 shows the FT-HSH2 grid for well AZ-17. The figure shows that the grid temperature of starting conditions was about $290^{\circ} \mathrm{C}$ while the reservoir steam $y$ was about $10 \%$. As in well AZ-6, the reference point indicates a lower temperature obtained from temperature logs. The overall tendency of the points in the grid shows a drop in the temperature but an increase in reservoir steam, which is the same trend as observed in well AZ-6. These results are a consequence of exploitation that causes pressure drop and boiling. Deep liquid boiling produces two-phase fluids rich in non condensable gases that increases $y$ values at reservoir. Data for 2001 in the grid, where $y$ is about $50 \%$, could reflect drilling operations in the field that caused anomalous results regarding gas equilibrium. The anomalous point with a high $y$ value (about $40 \%$ ) in fig. 4 corresponds to the sample taken one week before the September 1985 earthquake $(M S=8.1)$. According to the grid, the reservoir steam/liquid ratio temporarily changed as a result of the tectonic event (Barragán et al., 2001).

Well AZ-33 produces two phase fluids with an average steam fraction of 0.71 at wellhead 


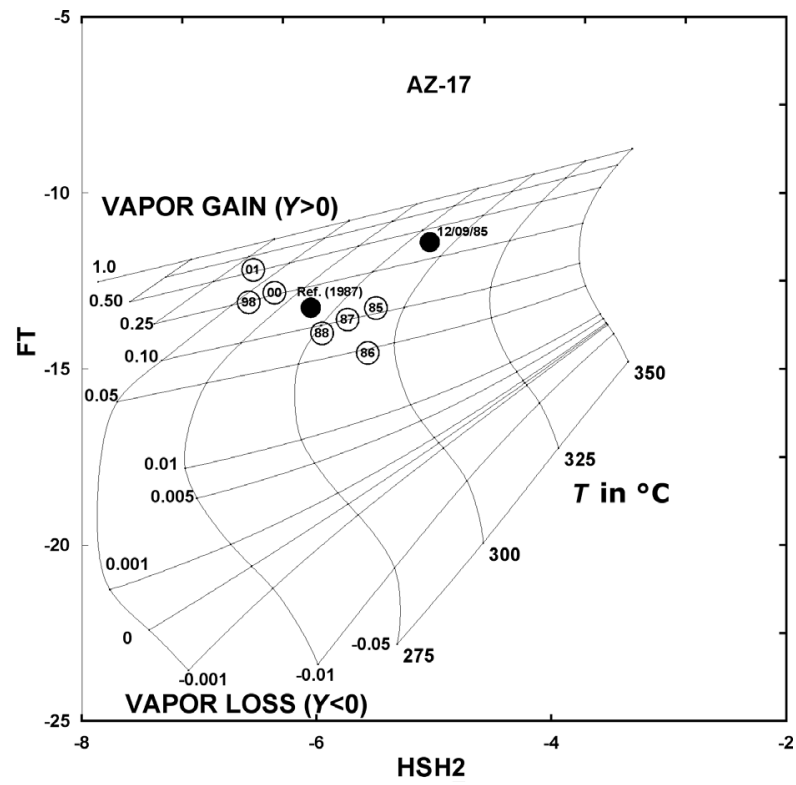

Fig. 4. FT-HSH2 grid diagram for well AZ-17. The dark dot shows the conditions taken as reference before exploitation (Nieva et al., 1987). Circles show the average values for the indicated years. See text for discussion.

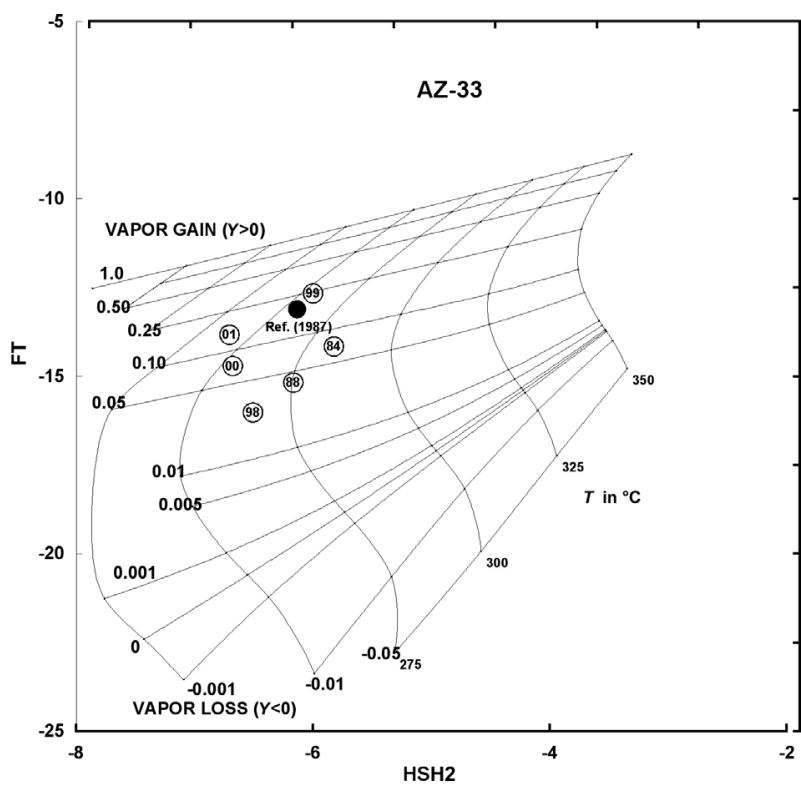

Fig. 5. FT-HSH2 grid diagram for well AZ-33. The dark dot shows the conditions taken as reference before exploitation (Nieva et al., 1987). Circles show the average values for the indicated years. See text for discussion. 
and it is affected by reinjection. The grid for well AZ-33 is given in fig. 5. The reference point taken in 1987 indicated an initial reservoir temperature of $270^{\circ} \mathrm{C}$ and an excess steam $y$ of $20 \%$ while results in the grid for the year 1984 show a temperature of $283^{\circ} \mathrm{C}$ and a $y$ of $6.5 \%$. The scattering shown by data in the grid is related to the influx of cooler fluids in an intermittent way, depending on reinjection. The data for 1984-1988 show a decrease in both the temperature and $y$. According to D'Amore and Truesdell (1995), this pattern indicates recharge of pure and low temperature water with no gas content as is the case with reinjection. For 1997-1998 data the CCG reservoir temperature was $256^{\circ} \mathrm{C}$ while the grid provided $265^{\circ} \mathrm{C}$. The relatively low value obtained by CCG is due to the admixture of lower temperature waters to the reservoir from reinjection. CCG provides the temperature «far» from the well, although the reinjected fluid has been heated during flow to the reservoir. The trend of variation found for 1998-2001 data shows the same pattern observed at wells AZ-6 and AZ-17, a decrease in temperature and an increase in $y$. The decrease in temperature is caused by the mixing of reservoir-cooler reinjection fluids whereas the $y$ increase is due to the deep boiling process induced by the drop in pressure that also releases non condensable gases. The same pattern observed for this well is shown at well AZ-46 which is also affected by reinjection.

\subsection{Maritaro liquid-dominated northern zone}

Wells AZ-5, AZ-13 and AZ-9 have been selected as representative of the north zone. Figure 6 shows the FT-HSH2 grid of well AZ-5. This well produced two-phase fluids in the past with an average steam fraction of 0.73 at separating conditions but at the present time the steam fraction has increased towards 0.89 in average. In fig. 6, the points corresponding to $1985-1987$ indicate reservoir temperatures of $275-280^{\circ} \mathrm{C}$ while the reference temperature (obtained by CCG) was $300^{\circ} \mathrm{C}$. Overall tendency for the points indicates an increase in temperature and a decrease in $y$.

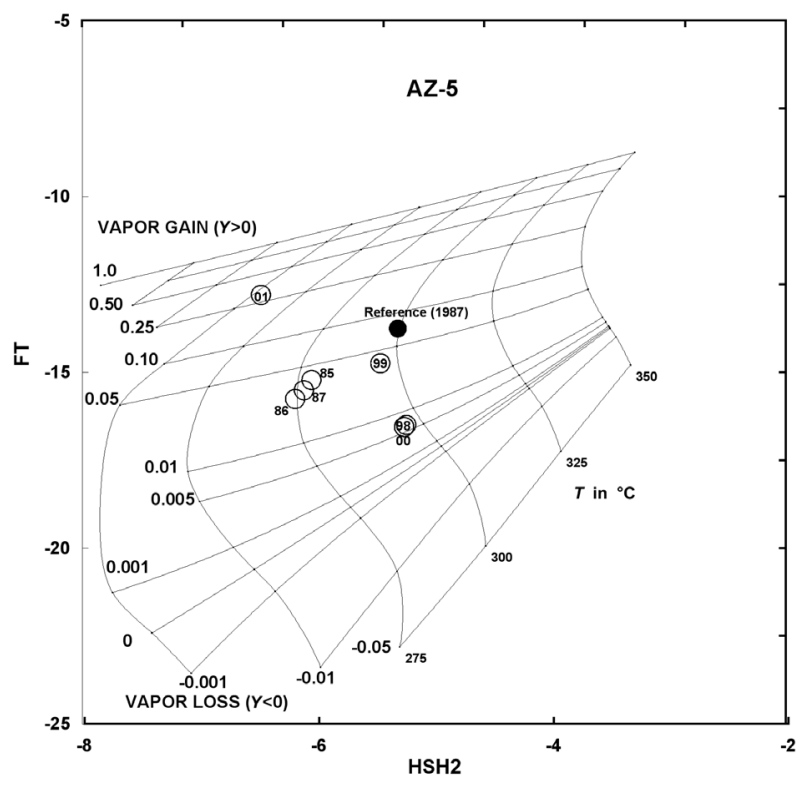

Fig. 6. FT-HSH2 grid diagram for well AZ-5. The dark dot shows the conditions taken as reference before exploitation (Nieva et al., 1987). Circles show the average values for the indicated years. See text for discussion. 
This pattern is interpreted as a result of the contribution of a hotter fluid with high liquid saturation from a deep source. However, production data indicate that an important boiling process takes place in this zone of the reservoir. The estimations of reservoir temperature obtained by silica and CCG geothermometers and the temperature obtained by the well simulation using the simulator WELFLO (Goyal et al., 1982) with time were compared according to Truesdell et al. (1995), (fig. 7). The silica geothermometer provides the temperature «close» to the well while the simulator provides the temperature of the fluid entering the well, thus both temperatures agree in most cases. In contrast, CCG provides the temperature «far» from the well because of its relatively slow reequilibration rate. As is seen, for 1985-1987 the grid temperatures are close to the silica estimations, indicating that temperature at which the last gas equilibria occur. The comparison of the gridCCG temperatures for Los Azufres wells suggest that as the wells produce higher steam fractions both temperatures approach each other (Barragán et al., 2002) as in the case of the 1998-2000 data. As noticed, a very low grid temperature for the year $2001\left(230^{\circ} \mathrm{C}\right)$ was found. The average values of $\mathrm{CO}_{2}$ at 2000 and 2001 changed from 966 to $902 \%$ molar (dry basis) whereas the $\mathrm{N}_{2}$ changed from 7.9 to $66.4 \%$ molar (dry basis). This change is related to drilling operations in this zone during 2001, that allowed the influx of air to the reservoir causing gas deviations regarding equilibrium. Reservoir steam values $y$ range between 0.5 and $5 \%$, indicating a high liquid saturation in the reservoir fluid.

The FT-HSH2 grid for well AZ-13 is given in fig. 8. In the past this well produced two-phase fluids but at present it emanates only steam. The figure shows that the grid reservoir temperature for initial conditions is $270^{\circ} \mathrm{C}$ which is rather low compared to the reference temperature of $300^{\circ} \mathrm{C}$, but, well-bottom temperature obtained by the

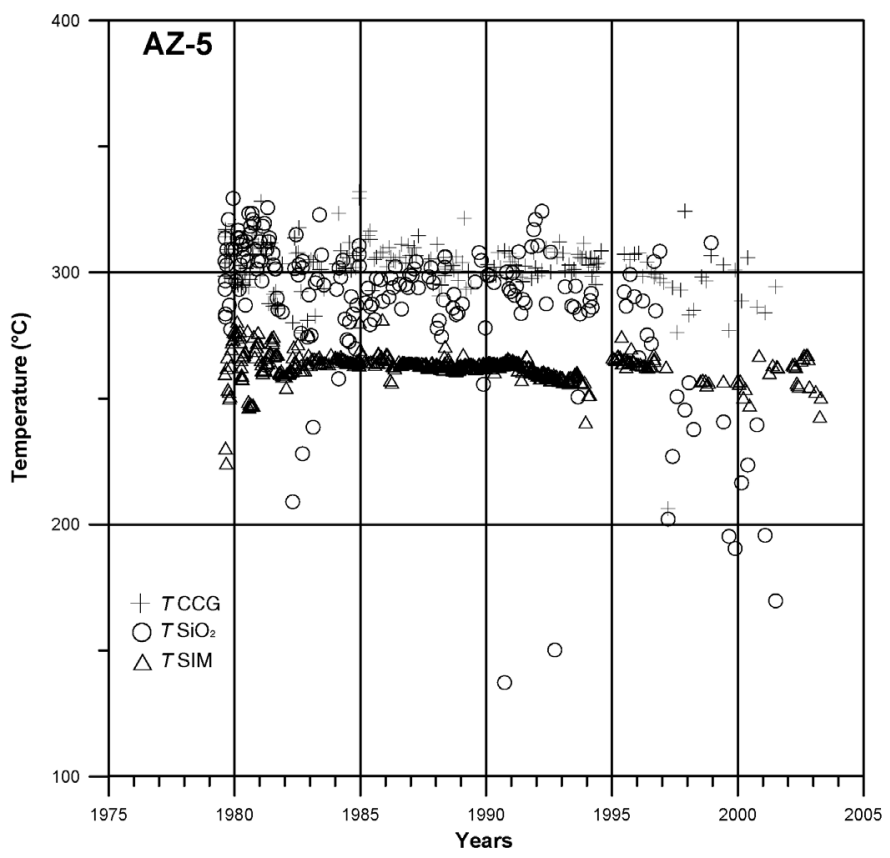

Fig. 7. Estimation of reservoir temperatures in well AZ-5 with time. TCCG: temperature estimated by CCG geothermometer; $\mathrm{TSiO}_{2}$ : temperature estimated by silica geothermometer and $T \mathrm{SIM}$ : temperature estimated by the well simulator WELFLO. 


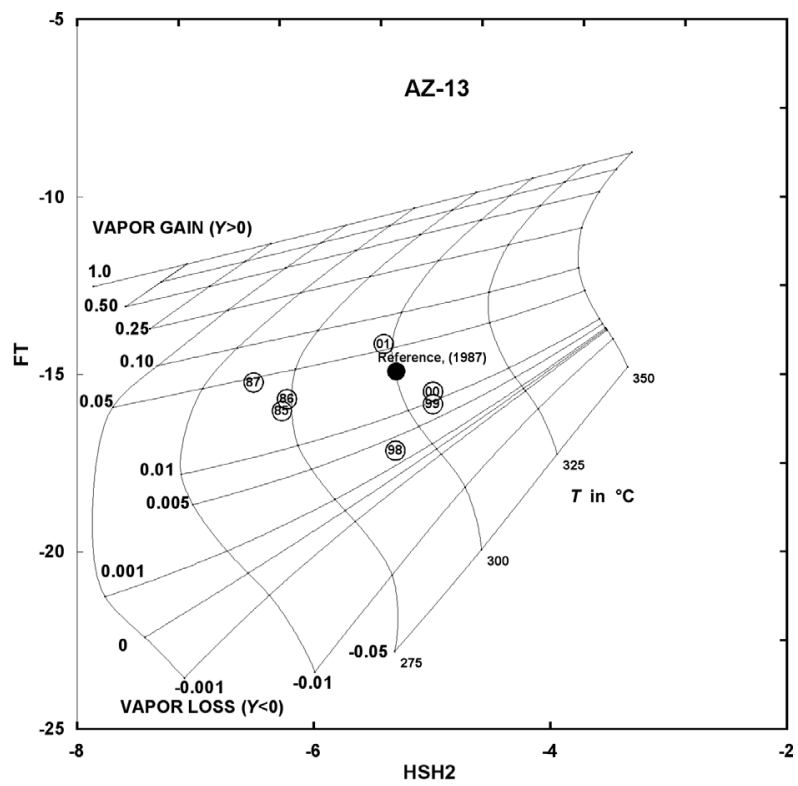

Fig. 8. FT-HSH2 grid diagram for well AZ-13. The dark dot shows the conditions taken as reference before exploitation (Nieva et al., 1987). Circles show the average values for the indicated years. See text for discussion.

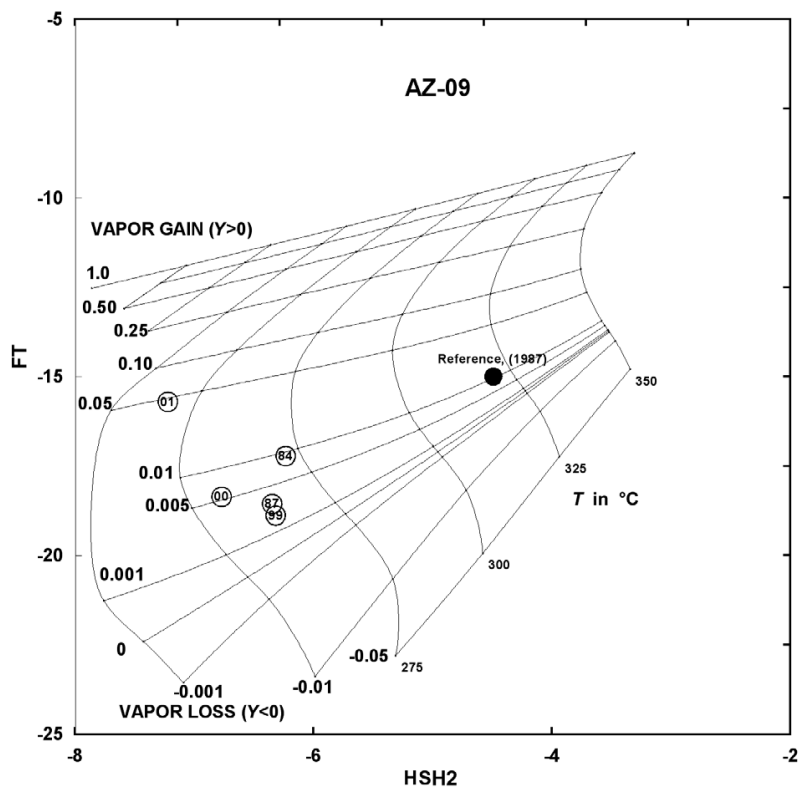

Fig. 9. FT-HSH2 grid diagram for well AZ-9. The dark dot shows the conditions taken as reference before exploitation (Nieva et al., 1987). Circles show the average values for the indicated years. See text for discussion. 
well simulator yields $275^{\circ} \mathrm{C}$. As the well changed towards vapor phase the grid method indicates reservoir temperatures close to (in 1998) or higher than (in 1999, 2000) CCG estimations given in the past. The temperatures higher than CCG estimations found for 1999 and 2000 (grid temperature of $310^{\circ} \mathrm{C}$ ) could be due to near-well boiling processes which increase the gas content in the fluid. The comparison of temperature estimations according to the method proposed by Truesdell et al. (1995) confirmed that near-well boiling occurred within the well until 1997 (Barragán et al., 2002). Data of 2001 were affected by drilling thus show a decrease in temperature $\left(295^{\circ} \mathrm{C}\right)$ and a higher value $(6 \%)$ of $y$.

Figure 9 shows the FT-HSH2 grid for well AZ-9. This well produces two phase fluids from the deep compressed liquid zone of the reservoir. The steam fraction at separating conditions was 0.32 in 1998. The grid temperature found for initial conditions was $270^{\circ} \mathrm{C}$ while the reference value based on CCG was $320^{\circ} \mathrm{C}$. The grid temperature in this well compares well with the temperature obtained by the well simulator $\left(280^{\circ} \mathrm{C}\right)$ providing the temperature of the fluid entering the well. The detailed analysis of chemical and isotopic data (Arellano et al., 2003) suggested that in spite of exploitation, this well shows stable conditions with time. This is also seen in fig. 9 since the points for 1987 and 1999 are located very close to each other in the grid. The point for the year 2000 indicates a reservoir temperature of $260^{\circ} \mathrm{C}$ which agrees with the well simulator temperature at present time. The year 2001 sample has been altered due to drilling in the field as in well AZ-5.

\section{Conclusions}

Gas equilibria prove to be suitable in Los Azufres geothermal field in defining a conceptual model for the natural state conditions at reservoir. Changes due to exploitation were observed in both zones of the field in the gas equilibria by means of FT-HSH2 grid.

Representative wells were studied using the FT-HSH2 method. For the south zone where reinjection is important, the FT-HSH2 grids for wells AZ-6, AZ-17 and AZ-33 show a decrease in temperature and an increase in $y$. This is due to the influx of fluids rich in gas as in the case of reinjecting fluids being water/air mixtures. The concentration of non condensable gases has increased in the southern zone of the field because of both processes: a deep boiling producing two-phase fluids rich in gas and water/air reinjection.

In the northern zone the wells AZ-5, AZ-13 and AZ-9 were studied. In wells AZ-5 and AZ13 an increase in temperature and a decrease in $y$ values are seen. This result is due to the higher vapor fraction produced by both wells at present time compared to lower values produced before. In the past, the wells were liquid-dominated and CCG and silica geothermometers indicated higher reservoir temperatures than those indicated by FT-HSH2 grid. As the grid provides the temperature for the last equilibrium, which occurs when the fluid enters the well, grid temperatures may not correspond to the fluid temperature in the «undisturbed» reservoir. Thus, the grid underestimates temperatures of both wells at initial conditions. This fact is clearly seen in well AZ-9 where, in spite of exploitation, stable conditions have been inferred. As this well is liquid-dominated, the grid temperatures approach those obtained by the WELFLO simulator. These are lower than those estimated by liquid phase geothermometers (CCG or silica), providing the temperature of the fluid entering the well.

When the vapor fraction is higher, the FT$\mathrm{HSH} 2$ grid provides better estimations of reservoir temperature at Los Azufres wells, comparable to $\mathrm{CCG}$ results. Although FT-HSH2 method is very useful in studying data from dry steam wells where no liquid phase is available, additional evidence based on production data should be investigated in order to better understand the trends in the FT-HSH2 grid.

\section{Acknowledgements}

The authors thank the Comisión Federal de Electricidad, Residencia Los Azufres, Eng. M. A. Torres R. for providing data and allowing publication of this work. The results were part of the project «Isotopic study of production and injection well fluids from the Los Azufres geot- 
hermal field» developed by CFE-IIE in 2002. The authors also acknowledge Dr. J. Heinicke and Dr. J. Walker and two anonymous reviewers for useful comments on the work.

\section{REFERENCES}

Arellano, V.M., A. García, R.M. Barragán, G. IzQuierdo, A. Aragón, D. Nieva, E. Portugal and I. TORRES (1998): Desarrollo de un modelo básico actualizado del yacimiento de Los Humeros, Puebla, Report IIE/11/11459/I 1/F (Instituto de Investigaciones Eléctricas, Temixco, Morelos), p. 450.

Arellano, V.M., M.A. Torres, R.M. Barragán, F. SanDOVAL and R. LOZADA (2003): Chemical, isotopic and production well data analysis for the Los Azufres (Mexico) geothermal field, Geotherm. Res. Coun. Trans., 27, 275-279.

Arnorsson, S. and E. GunNlaugsson (1985): New gas geothermometers for geothermal exploration-Calibration and application, Geochim. Cosmochim. Acta, 49 (6), $1307-1325$

Barragán, R.M., E. Santoyo, D. Nieva, E. Portugal and M. VERMA (1988): Caracterización de yacimientos geotérmicos mediante la determinación de parámetros físicoquímicos, Internal Report IIE/11/2386/I 01/F (Instituto de Investigaciones Eléctricas, Temixco, Morelos), p. 250.

Barragán, R.M., V.M. Arellano, D. Nieva, E. Portugal, A. García, A. Aragón, I. Torres and R. Tovar (1999): Geoquímica de gases del campo geotérmico de Los Humeros, Pue. (México), Geotermia, Rev. Mex. de Geoenergía, 15, 183-193.

Barragán, R.M., V.M. Arellano, D. Nieva, E. Portugal, A. García, A. Aragón, R. Tovar and I. Torres (2000a): Gas geochemistry of the Los Humeros geothermal field, México, in Proceedings of the World Geothermal Congress, Kyushu-Tohoku, Japan, 2527-2532.

Barragán, R.M., E. Portugal and A. Aragón (2000b): Estudio isotópico de fluidos de pozos productores y de reinyección del campo geotérmico de Los Azufres, Michoacán, Report (Instituto de Investigaciones Eléctricas, Cuernavaca, México), p. 144

Barragán, R.M., V.M. Arellano, E. Portugal, F. SanDOVAL and V.M. BARRERA (2001): Gas equilibria for the Los Azufres (Michoacán) geothermal reservoir, México, in Proceedings of the 22nd PNOC-EDC Geothermal Conference, March 10-12, Manila, Philippines, 81-87.

Barragán, R.M., E. Portugal, V.M. Arellano, A. Aragón and F. SANDOVAL (2002): Evolución isotópica de fluidos de pozos del campo geotérmico de Los Azufres, Michoacán, Ing. Hidrául. Méx., XVII, 99-113.

Cathelineau, M., R. Oliver, A. Garfias and D. Nieva (1985): Mineralogy and distribution of hydrothermal mineral zones in the Los Azufres (Mexico) geothermal field, Geothermics, 14, 49-57.

D’AMORE, F. (1992): Gas geochemistry as a link between geothermal exploration and exploitation, in Appl. Geochem. Geotherm. Reservoir Development (UNITAR/UNDP), 93-117.
D'AMORE, F. (1998): Time evolution of chemical and physical parameters of the reservoir fluid in Ahuachapan Geothermal Field (El Salvador), Report for the IAEA, p. 210.

D'AMORE, F. and R. CELATI (1983): Methodology for calculating steam quality in geothermal reservoirs, Geothermics, 12, 129-140.

D'amore, F. and C. PANichi (1980): Evaluation of deep temperatures of hydrothermal systems by a new gas geothermometer, Geochim. Cosmochim. Acta, 44, 549-556.

D'AMORE, F. and A.H. TRUESDELl (1985): Calculation of reservoir temperatures and steam fraction from gas compositions, Geotherm. Res. Coun. Trans., 9 (1), 305-310.

D'Amore, F. and A.H. Truesdell (1995): Correlation between liquid saturation and physical phenomena in vapor-dominated geothermal reservoirs, in Proceedings of the World Geothermal Congress 1995, Florence, Italy, pp. 1927-1931.

FOURNIER, R.O. and R.W. POTTER II (1982): A revised and expanded silica (Quartz) geothermometer, Geotherm. Res. Coun. Bull., November 1982, 3-12.

Giggenbach, W.F. (1980): Geothermal gas equilibria, Geochim. Cosmochim. Acta, 44, 2021-2032.

GigGENBACH, W.F. (1987): Redox processes governing the chemistry of fumarolic gas discharges from White Island, New Zealand, App. Geochem., 2, 143-161.

Goyal, K.P., S. Halfman, A.H. Truesdell and J. Howard, (1980): Production characteristics of some wells at the Cerro Prieto geothermal field, Report Lawrence Berkeley National Laboratory (Earth Sciences Division, LBL-15 500, Berkeley, CA7.

Iglesias, E.R., V.M. Arellano, A. Garfias, C. Miranda and A. ARAGón (1985): A one dimensional vertical model of the Los Azufres, México, geothermal reservoir in its natural state, Geotherm. Res. Coun. Trans., 9 (2), 331-336.

NiEVA, D. and R. NiEva (1987): Developments in geothermal energy in Mexico-Part Twelve, $A$ cationic geothermometer for prospecting of geothermal resources, Heat Recovery Systems and CHP, 7, 243-258.

Nieva, D., M. Verma, E. Santoyo, R.M. Barragán, E. Portugal, J. ORTíz and L. QuiJano (1987): Chemical and isotopic evidence of steam upflow and partial condensation in Los Azufres reservoir, in Proceedings of the Twelfth Workshop on Geothermal Reservoir Engineering, Stanford University, 253-259.

Siega, F.L., N.D. SAlonga and F. D'Amore (1999): Gas equilibria controlling $\mathrm{H}_{2} \mathrm{~S}$ in different Philippine geothermal fields, in Proceedings of the 20th Annual PNOC-EDC Geothermal Conference, March 10-12, Manila, Philippines, 29-35.

TARAN, Y.A., T.P. Fischer, E. Cienfuegos and P. Morales (2002): Geochemistry of hydrothermal fluids from an intraplate ocean island: Everman volcano, Socorro Island, México, Chem. Geol., 188, 51-63.

Truesdell, A.H., M.J. Lippmann, J.L. Quijano and F. D'AMORE (1995): Chemical and physical indicators of reservoir processes in exploited high-temperature liquid-dominated geothermal fields, in Proceedings of the World Geothermal Congress, Florence, Italy, vol. 3, 1933-1938. 